\title{
An Interview with Leonardo Nieva Mercado, SVD
}

\section{Emmanuel C. De Leon and Marvin Einstein S. Mejaro}

\begin{abstract}
In this interview, we closely encounter to one of the most important contemporary Filipino philosophers who started to pick up the pieces of what he dubbed as "elements of Filipino philosophy." The interviewers highlight the intellectual biography of Leonardo Mercado beginning from his childhood in Cebu, his seminary formation, his transfer to the University of Santo Tomas, the context of his venturing into Filipino philosophy, and his estimation concerning the status of Filipino philosophy that he pioneered. Additionally, Mercado's thought-provoking comments and reactions concerning the insights of other scholars who reflect on Filipino philosophy are also presented.

Keywords: Mercado, Thomasian philosophers, Filipino philosophy, culture
\end{abstract}

\section{A Child of Cebu City}

Emmanuel de Leon (Interviewer): Father Mercado, you were born in Cebu Maternity Hospital on March 16, 1935. And you moved to Manila, and then to Quezon City. Father, please tell us something about your childhood in the province. How many are you in the family?

Leonardo Mercado: Childhood? Well, we were five. I was the eldest; then Lito and Marita. The youngest were twins - boy and girl. The girl died after two years due to meningitis. That time wala pa iyang cure, kasi panahon pa iyan ng mga Hapon (There was no available cure to meningitis during the time of Japanese Occupation).

De Leon: And how about your parents?

Mercado: My father, Manuel Mejia Mercado, was a dentist from Cebu. And, my mother, Engracia Jamin Nieva, was a nurse from Marinduque who decided to work at Cebu during that time. When my father died on 


\section{INTERVIEW WITH LEONARDO MERCADO}

[November 20] 1945, and my mother was employed as nurse at Philippine Tuberculosis Society [in Pasay City], we move to Manila from Cebu.

De Leon: Do you think there is a connection between your childhood experiences in Cebu and your academic work?

Mercado: Anything about philosophy when I was a boy, maybe none. I was simply a boy and nothing philosophical in me during that time.

De Leon: When it comes to your basic education in Cebu, how will you describe it? Where did you get your elementary and high school degrees?

Mercado: Okay. It was Japanese Occupation or Second World War. My Grade 1 and Grade 2 were with the RVM sisters ${ }^{1}$, and then came the bombing. ' $D i$ ba binomba 'yan ng mga Amerikano? (Do you remember that it was bombed by the American soldiers?). So, we had to evacuate. We had to move from the province to the city and then to Bohol. Our house was burned because it was near the convent and the University (of San Carlos). That was a Japanese concentration camp, so it was bombed and the fire went as far as our place. The whole area was destroyed. I continued my elementary studies at Saint Theresa's College; then I transferred to Cebu Normal School for my grade 5 until I finish High School.

De Leon: And what about the religiosity of your family, and your own religiosity when you were just a kid? Was it your dream to become a religious priest?

Mercado: Nothing at that sort. Well, my father was a religious person. I would say he would pray before he goes to bed and in cases such as [the celebration of] Corpus Christi, he would be among the ones who would carry the ... Ano bang tawag doon? (How do you call that?)

De Leon: Kubol?

Mercado: Hindi yata [kubol] (I don't think so). That was the thing that people carry to cover the Blessed Sacrament. He was very active on church activities.

De Leon: So, it was not your dream to become a religious priest?

\footnotetext{
${ }^{1}$ It was a parochial school named Santo Rosario which was ran by the (Religious of the Virgin Mary (RVM) sisters during that time.

(C) 2016 Emmanuel C. De Leon and Marvin Einstein S. Mejaro http://www.kritike.org/journal/issue 19/de leon\&mejaro december2016.pdf ISSN 1908-7330

(c) BY-NC-ND
} 
Mercado: No, it was not my dream.

De Leon: What led you to Christ the King Seminary?

Mercado: Well, I could not find money to pay my tuition in Mapúa [as an Engineering student], so I dropped out [laughs]. And this guy offered free tuition fees in the seminary, so I took it [laughs]. Just like that kind of "you lose nothing" if you enter this school [laughing out loud].

Marvin Einstein Mejaro (Interviewer): Father, in connection with what Emman asked earlier, why S.V.D.? Was that deliberate as well?

Mercado: Well, I was in an S.V.D. school, San Carlos University, and with these S.V.D. priests, and so on and so forth. That was the natural connection. I didn't think of other congregation nor diocesan [formation].

De Leon: You are known as a solid academician, a brilliant philosopher. And, the S.V.D. congregation is also known as missionaries. How do you balance the two?

Mercado: Mission has many levels. Mission activity can be in terms of running a parish. The other level of mission is when it comes to education.

De Leon: And you were ordained in Rome in 1964. Tell us something about your experiences abroad.

Mercado: At that time, there was this policy of the Generalate to cross-enroll. During that time, there were Germans studying in America, Americans studying in Germany, Filipinos studying in Rome. I was one of the seminarians who were sent to Rome to study. Our class was international. We were eleven: there were Indonesians, Americans, Germans, Argentineans, and we were two Filipinos. So, halo-halo na 'yan doon (So, we have mixed cultures in the formation).

De Leon: You studied philosophy or theology?

Mercado: That was [Licentiate] in Theology.

\section{In UST and the Beginning of Writing on Filipino Philosophy}

De Leon: Now, what led you to study in our alma mater, UST?

(C) 2016 Emmanuel C. De Leon and Marvin Einstein S. Mejaro http://www.kritike.org/journal/issue 19/de leon\&mejaro december2016.pdf 


\section{INTERVIEW WITH LEONARDO MERCADO}

Mercado: Formerly, I was studying in [University of] San Carlos in Cebu. I enrolled there for one semester. But, that time, the main philosopher there died. So, I transferred to UST.

Mejaro: How was UST then, Father? Particularly the program in philosophy back then?

Mercado: That time, as you know, UST was traditionally scholastic. Then came in Dr. [Emerita] Quito; she was a new wave, as we know it. She was one of my teachers as well. She brought in new ideas and atmosphere here in UST. She introduced existentialism, structuralism, etc.

De Leon: Aside from Dr. Quito, who do you think are your influences? Who are the UST professors that influenced you the most?

Mercado: Nobody was significant, except Quito [laughing out loud]. In fact, Dr. Quito did not support my ideas. She was supposedly my dissertation adviser, but she did not advise me and she was not present during my dissertation defense [laughs].

Mejaro: Father, the way I read it, it seems to me that from the very start it was deliberate from you that you want to curve a different place in philosophy.

Mercado: As I was saying in one of my essays, it's a form of nationalism. Nationalism should not be just personal; it must also be intellectual. The idea of "intellectual nationalism" was absent during that time. We can be Filipino through citizenship, but in reality we are "tuta" ("puppy"; colloquial term for "puppet").

De Leon: You called that "tuta ng isip" in one of your articles.

Mercado: Yes, "tuta ng isip." We followed Kierkegaard, we followed Sartre; We were colonized by them-hindi tayo malaya [sa isipan] (There was intellectual colonialism). So, I was trying to highlight a new form of nationalism during that time.

Mejaro: Father, I'm also interested in the topic of your dissertation. At that time, your dissertation seems to create a new path to a different topic. At that time, were you also doubting about the idea of a Filipino philosophy?

Mercado: No.

(C) 2016 Emmanuel C. De Leon and Marvin Einstein S. Mejaro http://www.kritike.org/journal/issue 19/de leon\&mejaro december2016.pdf ISSN 1908-7330

(c) $)$ BY-NC-ND 
Mejaro: So, you are sure that it will create something different?

Mercado: I was just doing what I thought was correct.

De Leon: Can we say that your dissertation is a sort of "revolt" against the system during that time?

Mercado: Pwede nga 'yan (You can say so). In fact, if you ask during that time: "Meron bang Filipino philosophy?" ("Is there a Filipino philosophy?"), that was a very big question back then. Even our professors did not know Filipino philosophy. For them, there is only one philosophy.

Mejaro: Did you feel the necessity of posing that question during that time? Some scholars would say we don't need to pose this question. We should just do philosophy. For me, I see the need of posing this question to reassess where we are.

Mercado: Actually, I had a German teacher before saying that there is only one kind of philosophy-scholastic philosophy. Indian philosophy is not philosophy [according to him]; that kind of mindset that only Greeks can do philosophy and scholasticism was the only philosophy.

Mejaro: Meaning, there was a necessity of asking that question.

Mercado: Yeah.

\section{On the Status of Filipino Philosophy}

De Leon: In your 2005 article "Why I Started to Write on Filipino Philosophy," you observed that "The literature on Filipino Philosophy is ... growing. But the idea of Filipino philosophy was unthinkable when I started writing on it in the early 1970s"2. Father, what do you think is the current status of Filipino philosophy compared to the time when you were starting to write about it?

Mercado: Now?

De Leon: Yes.

${ }^{2}$ Leonardo N. Mercado, "Why I Started to Write on Filipino Philosophy," in Essays on Filipino Philosophy (Manila: Logos Publications, Inc., 2005), 11.

(c) 2016 Emmanuel C. De Leon and Marvin Einstein S. Mejaro http://www.kritike.org/journal/issue 19/de leon\&mejaro december2016.pdf ISSN 1908-7330 


\section{INTERVIEW WITH LEONARDO MERCADO}

Mercado: Well, my peers like Alfredo Co, Romualdo Abulad, and so forth, are doing great. Once in De La Salle University, there was a meeting there. Their philosophy department invited several Filipino philosophers. Of course, Dr. Quito was invited but she was just busy taking pictures [laughs]. Even Manny [Manuel] Dy [Jr.] and his colleagues in Ateneo were present in the said event. They gave talks and lectures.

De Leon: Is there an improvement or a decline when it comes to the status of Filipino philosophy?

Mercado: We can say that quot capita, tots sensus (so many heads, so many opinions). Bawat isa ay may kanya kanyang ideya tungkol sa Filipino philosophy. (Everybody has his own idea concerning Filipino philosophy). I think, pluralism is good, but my suggestion is that we must come together and stick to one topic. People write but there is no common theme-sabog-sabog (no common theme)! There is no common question! We do not talk to each other concerning our methodology. We should also stick to one topic, so that we can compare notes. Because, somebody said, "Kung walang written philosophy, walang philosophy" ("If there is no written philosophy, then there is no philosophy"). Parang sinasabi na kung walang nakasulat, ibig sabihin ay wala na agad pilosopiya (They seem to suggest that an absence of written material necessarily implies absence of philosophy). I don't agree with that.

For example, there is a group of Aborigines in Australia [whose] grammar is not written in textbook. But, they speak their own language. Ibig sabihin ba na kung walang nakasulat na grammar, wala na ring grammar ang mga tao? Hindi! (Does the absence of a written grammar necessarily mean that people do not have grammar? I don't think so!). Grammar is how you use the language. It is the language being spoken. So, the people speak the language, ang problema lamang ay walang written grammar (the only problem is that their grammar is not written in books). So, how do you make a written grammar? From the usage, you can infer the rules of grammar; that's the same thing in Filipino philosophy.

But, there are so many ideas. Okay, let's stick with one theme. In one event, we talk about "philosophy of man." In another event, we talk about "philosophy of knowledge" so we can compare notes. We can be acquainted with the project of each other. Kanya-kanya kasi tayo ng scope (Everybody has his own personal philosophical scope). I agree with the importance of pluralism, but let's stick to one theme. That challenge remains a challenge.

De Leon: What you just said has something to do with methodology. We can say that you designed your own methodology, that is, inference from

(C) 2016 Emmanuel C. De Leon and Marvin Einstein S. Mejaro http://www.kritike.org/journal/issue 19/de leon\&mejaro december2016.pdf ISSN 1908-7330

(c) $)$ BY-NC-ND 
language structures and from words. What influenced the formation of your own methodology?

Mercado: When I was in a vacation in Italy, I asked some Linguistic scholars and they showed me some references. I fused the method of linguistics (as a science) and philosophy of language.

Mejaro: Father, why do we need to start from language? It seems that from your very first book it is also deliberate.

Mercado: I said there are many ways [of doing philosophy]. And, one of the methods is to infer philosophy through language. Kung anong behavior mo, may kinalaman 'yun sa pag-iisip mo. For example, a young man, anong kilos niya?: Meron siyang sinusulat, dinadalaw niya ang isang dalaga sa isang address, may dala siyang rosas. Ibig sabihin, sa kanyang mga kilos makukuha mo ang isang kongklusyon na "Siya ay umiibig!" Iyan 'yung mga pahiwatig, 'di ba? (Your behavior has something to do with the way you think. For example, imagine the actions of a certain man. Imagine him writing, and visiting a young woman. He has brought with him a bundle of roses. From that set of actions, we can deduce that "he is in love!" Those are the implications, right?). There is a point of inference in behavior. The same thing with Filipino behavior. They can be inferred in language, as well as in signs and symbols. From them we can say there is a convergence also. So, you infer from language and behavior.

Another example, when we see someone, we usually ask, "Saan ang punta mo? Bakit nag-iisa ka?" ("Where are you going? Why are you alone?"). Do we consider that as an insult? In some cultures, they see that as minding the business of other people. But that's different for us. When you say in Ilokano, "Papanam?" or "Where are you going?", was that an insult?

De Leon: No, Father? That's a form of greeting for most of us.

Mercado: Yeah. That's what I was trying to say.

De Leon: But, aside from the method of inference in language, have you conducted some fieldworks concerning Filipino Philosophy?

Mercado: As written down, there is none. There are existing [fieldwork that I have done] but they are not published.

(c) 2016 Emmanuel C. De Leon and Marvin Einstein S. Mejaro http://www.kritike.org/journal/issue 19/de leon\&mejaro december2016.pdf ISSN 1908-7330 


\section{INTERVIEW WITH LEONARDO MERCADO}

De Leon: There is a method in the field of history which they call "history from below." Is it deliberate on your part to do also "philosophy from below"?

Mercado: Yeah, we can call it "philosophy from below" - philosophy from the people. I called it "from the implicit to the explicit." People "practice" their philosophy, but they did not write something about it.

De Leon: So, for you, what should be the role of a philosopher?

Mercado: When it comes to the role of a philosopher, I used the analogy of a "partera" or a "midwife." Does the midwife give birth? Hindi! (No!) She simply assists in the process. Ang manganganak ay 'yung babae-ikaw lamang ay isang tumutulong sa panganganak (The woman will be the one to give birth-you simply assist in the process of giving birth). In the same way, people "know" philosophy and the role of the philosopher is to assist. You are just a facilitator. Hindi ikaw ang nanganganak sapagkat nariyan na iyan (It does not originate from you because it is already there).

Mejaro: Father, pwede po ba nating sabihin na bulky po talaga ang work na pagsisimulan natin sa Filipino philosophy like we are starting in language, behavior. Pwede po ba nating sabihin that the process is quite demanding? (Father, can we say that the task of doing Filipino philosophy is quite bulky, like we have to start in language and behavior? Can we say that the process is quite demanding?)

Mercado: No. In my case, my first article was on Filipino philosophy of time [Solidarity, 1972]. I used there the method of linguistics and observation of behavior. So, parang buo na naman iyon eh; Nandiyan na ang mga iyan. (It's like there is already a foundation; It's already there.) From your previous research, then come up with another topic related to that. It is easier doing that.

\section{Reactions to Mercado's Philosophy and Methodology}

De Leon: Father, have you read books and articles reflecting on Filipino philosophy authored by other Filipino philosophers?

Mercado: Now?

De Leon: Now and before? Have you read the works of other thinkers reflecting on Filipino philosophy like Ferriols, Timbreza, Quito, Abulad, etc.?

(C) 2016 Emmanuel C. De Leon and Marvin Einstein S. Mejaro http://www.kritike.org/journal/issue 19/de leon\&mejaro december2016.pdf ISSN 1908-7330

(c) ) BY-NC-ND 
Mercado: Well, Ferriols was not writing about "Filipino philosophy." That was not his concern. His only concern is his idea of "Meron" [laughing out loud]. He was also struggling to come up with his own philosophy, as far as we know he got stuck with "Meron" [laughs]. Wala namang more specific na [contribution], hindi ba? (It seems that his contribution to Filipino philosophy is not that specific).

De Leon: That's an interesting comment [laughs]. If you are going to mention a specific title or idea of a certain Filipino philosopher, what do you think is closer to your basic concepts?

Mercado: Well, one Jesuit priest is following me. Sino nga 'yun? (What is his name?)

De Leon: Albert Alejo?

Mercado: Yeah. Alejo. In fact, his dissertation is based on my concept of Filipino philosophy - my concept of "kalooban," 'di ba?3

De Leon: Do you agree with his re-appropriation of your concept of "kalooban"?

Mercado: Yeah. In a way, I agree with him. In fact, his basic methodology was coming from my writings. He seems to continue my basic questions.

De Leon: Usually, when they categorize Filipino philosophers, you will go with Florentino Timbreza. ${ }^{4}$ Do you agree with that? Maybe because you and Dr. Timbreza were doing something related to culture.

Mercado: Yeah. But, I'm not sure about his methodology. Parang "sabog" (It seems to be "disorganized") [laughing out loud]. I cannot measure my concepts in relation to his style of doing philosophy.

${ }^{3}$ See Albert Alejo, Tao po! Tuloy!: Isang Landas ng Pag-unawa sa Loob ng Tao (Quezon City: Office of the Reaearch and Publications - School of Arts and Sciences, Ateneo de Manila University, 1990).

${ }^{4}$ In the Introduction to his Filipino Philosophy: A Critical Bibliography, 1974-1997, Rolando Gripaldo categorizes Mercado and Timbreza as Filipino philosophers using "anthropological" or "cultural approach." See Rolando Gripaldo, Filipino Philosophy: A Critical Bibliography, 1974-1997, $2^{\text {nd }}$ edition (Manila: De La Salle University Press, Inc., 2000), 4.

(C) 2016 Emmanuel C. De Leon and Marvin Einstein S. Mejaro http://www.kritike.org/journal/issue 19/de leon\&mejaro december2016.pdf ISSN 1908-7330 


\section{INTERVIEW WITH LEONARDO MERCADO}

De Leon: Have you encountered the works of F.P.A. Demeterio III who evaluated the status of Filipino philosophy after 30 years of the publication of your book? He also evaluated the directions for Filipino philosophy. Do you have specific comment about it?

Mercado: I gave you the article related to that. In that article that I gave you, I already discussed my comments and suggestions. ${ }^{5}$ Just read it! Can you give me other authors who labor on Filipino philosophy? ${ }^{6}$

De Leon: Here in UST we have R.T. Pada. He wrote an article titled "The Methodological Problems of Filipino Philosophy."

Mercado: I don't know him yet. Sino pa? (Who else?)

Mejaro: Si Emmanuel Batoon po.

Mercado: I think he is writing his dissertation on me, 'di ba? (is it so?)

De Leon: He wrote articles about your anthropological approach in doing philosophy. ${ }^{7}$

Mercado: I know it exists but I haven't read his articles [laughing out loud]. Nasa Kritike 'yun, 'di ba? (Was it published in Kritike?)

De Leon: Yes, Father! Let's talk about some points mentioned by R.T. Pada. In his paper, Pada surveyed the method of several Filipino philosophers. He comments, "There is a certain sense of ambiguity when Mercado tries to assert that tools and methods in evaluating Filipino philosophy ought to be done in a non-Western category. This problem is further complicated by the fact that Mercado often cites Western philosophies to found most of his arguments ...." ${ }^{8}$ How will you comment about this, Father?

Mercado: Okay. Methodology wise, it is inference through language. Is this method limited to any nationality? Another method is inference from

\footnotetext{
5 See Leonardo N. Mercado, "Reflections on the Status of Filipino Philosophy," in Kritike, 10:2 (2016)

${ }^{6}$ In the recent previous issues of Kritike, the works of Batoon and Pada have dealt with Filipino philosophy. See footnote numbers 6 and 7.

7 See Emmanuel Batoon, “Tracing Mercado's Anthropological Perspective (First of Two Parts)," in Kritike, 8:1 (2014), 1-23. See also Emmanuel Batoon "Tracing Mercado's Anthropological Perspective (Second of Two Parts)," in Kritike, 8:2 (2014), 1-18.

${ }^{8}$ Roland Theuas DS. Pada, "The Methodological Problems of Filipino Philosophy," in Kritike, 8:1 (2014), 31.
}

(C) 2016 Emmanuel C. De Leon and Marvin Einstein S. Mejaro http://www.kritike.org/journal/issue 19/de leon\&mejaro december2016.pdf ISSN 1908-7330

(c) $)$ BY-NC-ND 
behavior. Is it confined to any nationality? Hindi! (No!) Anybody can use this tool to analyze a worldview, 'di ba? (right?) So, hindi ibig sabihin kapag Ilokano, hindi na pwedeng gumamit ng pamamaraan ng mga Tagalog. (Being an Ilocano does not hinder you to apply a method being used the Tagalogs).

Mejaro: So, Father, can we also say that we should also invite ambiguity in language because it's also necessary?

Mercado: No. What I was saying is that the language contained philosophy. Nandoon na [sa wika ang pilosopiya]. (Philosophy is an element of language). You simply explicate it. Again, the analogy of unwritten grammar that I mentioned a while ago. The rules of grammar must be inferred from the existing practices. If you talk about Filipino worldview, behavior, and so forth, nandoon ang mga 'yan [sa mga tao] (people embody their lifeworld). But, how do you make them explicit? That's another question. These are the methods that I found useful. If you find other useful methods, okay then, show it to me!

De Leon: So, the method should not be an "original" one?

Mercado: Not necessarily.

De Leon: Another comment that Pada posed is that your idea of Filipino philosophy is ahistorical. Meaning, "it neglects that significant influence of colonial forces that have shaped and affected the Filipino behavior." $9 \mathrm{He}$ pointed out the absence of Spanish and American influences in your study of Filipino volkgeist. How will you comment, Father?

Mercado: For example, I talked about "kalooban" based on the language and behavior of the people. There you infer philosophy. What is "ahistorical" in that method, 'di ba? (is it?) The language exists. In other words, the language is historical. I used the tool of inferring from the existing or historical language of the people. Then, what is "ahistorical" in my method? I don't understand that.

De Leon: Maybe Pada was pointing out that the "Filipino" is a by-product of different influences.

Mercado: I agree with that. But, the question is "yung "Filipino" ba ngayon ay iba sa "Filipino" noong araw? Pareho ba o hindi? (Is today's concept of being

${ }^{9}$ Ibid.

(c) 2016 Emmanuel C. De Leon and Marvin Einstein S. Mejaro http://www.kritike.org/journal/issue 19/de leon\&mejaro december2016.pdf ISSN 1908-7330 


\section{INTERVIEW WITH LEONARDO MERCADO}

"Filipino" different from that concept of being "Filipino" in the past? Yes or no?)

De Leon: It's analogous - partly the same and partly different.

Mercado: Let's put it this way. 'Yun bang Ingles ni Shakespeare kung ikukumpara sa Old English, pareho ba sila? Magkaiba sila! Pero, Ingles pa rin. (Is the Shakespearean English the same compared to Old English? They are different! But, it's still English.) Language, as well as culture, will always change. But, the question is, "Is today's English totally different from the old one?" Another thing is, "Are you the same person ten years ago and now?"

De Leon: The same and different [laughs].

Mercado: The human cells change every seven years, 'di ba? We have new set of cells every seven years. There is the sameness and difference. So, there is continuity also. Same thing in being Filipino-there is growth. There are sameness and difference.

De Leon: So, is it your project to look for that "sameness" in Filipino worldview?

Mercado: No. That is not my project. I just want to make them more explicit.

De Leon: You simply describe what is there?

Mercado: Yes. What is ahistorical there? [laughs].

\section{The Language Use and Intellectual Colonialism}

De Leon: Let's talk about your use of language in doing Filipino philosophy. You wrote it somewhere that writing in Tagalog during the 1970s was not yet fashionable. Do you think your observation is still valid today?

Mercado: That is because we live in a globalized world. They say, "The world must speak English." So, it is a tool. There are also technical terms that you cannot translate in Filipino language. The thing is, we must use the colloquial language or the language being use by the people. That is the living language or living reality.

De Leon: Komportable din po ba kayo sa paggamit ng Filipino? (Are you comfortable in using the Filipino language?)

(C) 2016 Emmanuel C. De Leon and Marvin Einstein S. Mejaro

http://www.kritike.org/journal/issue 19/de leon\&mejaro december2016.pdf

ISSN 1908-7330

(c) $)$ BY-NC-ND 


\section{Mercado: Yeah.}

Mejaro: Father, I observe that there is a certain kind of "hybridity" in your writings, meaning you can jump from philosophy to theology. You have Elements of Filipino Philosophy, Elements of Filipino Theology, on Filipino ethics, to name few. How do you see all these things, Father, in terms of your philosophizing?

Mercado: I don't see any problem in doing that.

Mejaro: Because it is good to point out that we are open to other fields - that philosophy is not narcissistic of its own system. Parang 'yan po ang nakikita ko doon. (That's what I observed in your style of doing philosophy).

De Leon: In relation to the point of Einstein, Father, you were also cited in the field of sikolohiyang Filipino, anthropology, social science, etc. Do you intend to influence in the said areas of knowledge?

Mercado: I don't have that intention to be cited [laughs]. I organized several conferences in sikolihiyang Filipino [in Tacloban]. I participated in theological conferences. I spoke in Iran about Muslim studies. So, it is multidisciplinary. I think philosophy can go to any domain. And, we must use different sciences of our time.

De Leon: In relation to that, what role do you think Filipino intellectuals, in general, and Filipino philosophers, in particular, should play in the development of public debates and public policies? How are we going to be relevant to Philippine society?

Mercado: Okay. The goal is the development of the Filipino people and to have what we call "kasarinlan" (autonomy). That should be the main focus. The point is sometimes when we embrace other cultures there is a tendency to be dominated by that culture. Parang nagiging alipin tayo (we tend to become slaves). Unlike the Japanese, they maintain their independence, scholars can accept foreign things, but they know their being Japanese. So, the thing here is our being "imitators" - gaya-gaya tayo malimit sa iba. Kung anong mayroon sa kanila, dapat mayroon din dito sa atin [kahit hindi naman lapat sa ating sitwasyon]. (Most of the time, we imitate Western culture. We want to imitate their unique way of life even if they are mismatched with our situation).

(c) 2016 Emmanuel C. De Leon and Marvin Einstein S. Mejaro http://www.kritike.org/journal/issue 19/de leon\&mejaro december2016.pdf 


\section{INTERVIEW WITH LEONARDO MERCADO}

We have our own philosophy and thinking, and we should be free to do that. Unless you are colonized intellectually by some cultures, then you will think that we are inferior. Then you will quote foreign philosophers because they are your heroes [laughs]. We should be free and not a slave.

De Leon: When it comes to the status of doing philosophy in our country, are we in the right track? What are we doing wrong and what are we doing right?

Mercado: Let's begin small. Let's have a seminar on different themes. For example, a seminar on "kalooban." Let's invite speakers who are Ilokano, Bisaya, Bikolano, etc. Okay. We may agree or disagree on that seminar, but that is healthy. Then, next time we talk about different topic like values or education. The discussion must only have one topic and let's find what is "Filipino" in that topic of discussion. Let's begin with some building blocks.

That's my proposal to different philosophical societies. Let's have a series of seminars on only one topic, then discuss, compile, print, and debate about them. Eventually we have a corpus of Filipino philosophy.

De Leon: Father, binabasa po ba ninyo ulit 'yung mga nasulat na ninyong libro? (Do you reread the books that you've written?)

Mercado: Oo naman. Meron din. (Yes. Sometimes.)

De Leon: When was the last time that you reread Elements of Filipino Philosophy? [laughs].

Mercado: Pero, nasulat ko na 'yan (But, I've written that already), why should I read? [laughs].

De Leon: If there is something that you are going to revise in your book Elements of Filipino Philosophy what is that?

Mercado: Wala naman akong nakitang kakaiba eh [laughing out loud]. Kasi ganito: halimbawa nagtatayo ka ng building, hindi ba mayroong pundasyon? Kung gusto mo pang magkaroon $n g$ second floor, third floor, fourth floor, kahit ilan pa idagdag mo riyan, ang mahalaga ay mayroon nang matibay na pundasyon. (I did not see anything inconsistent in my book. It's like when you are building a structure, foundation is the most important. If you still want to construct a second, third, fourth, or as many floors as you want, it is important that you have a solid foundation).

(C) 2016 Emmanuel C. De Leon and Marvin Einstein S. Mejaro http://www.kritike.org/journal/issue 19/de leon\&mejaro december2016.pdf ISSN 1908-7330

(c) ) BY-NC-ND 
Mejaro: So, Father, is it also deliberate na parang may progression talaga akong nakikita sa works ninyo? Na sa first book hanggang sa ngayon doon pa rin nanggagaling sa naunang libro? (So, Father, is it also deliberate on your part that I can see a progression in your works? You are consistent from the very start until now that you still go back to the fundamental theses of your first book?

Mercado: Yeah. Mayroong ibang aplikasyon na (Some are applied already). I applied it to law, ethics, psychology, theology. Philosophy can go anywhere.

Mejaro: Father, ano po yung mga binabasa ninyo ngayon? O mga projects na gusto pa ninyong gawin? (Father, what are you currently reading? Or do you have projects in progress?

Mercado: Projects? Wala namang projects [laughing out loud] (I don't have projects). Sometimes you are assigned to teach a particular course, I write my lectures, compile them, edit, and then publish. My books are like that. They are series of articles delivered in different fora.

Mejaro: May niluluto po ba kayong topic ngayon about certain matter? (As of the moment, do you plan to write concerning a certain topic?).

Mercado: I'm teaching now. There are some brilliant ideas inside the classroom and I'm planning to write about them for publication.

De Leon: If you are going give some pieces of advice to budding Filipino philosophers, those who want to follow your footsteps, what is that?

Mercado: Okay. That's a good question! Advice? I would say stick to one theme that is near to your heart. Then, write it down! Like the analogy of a drop of water. That is very small, but it will surely make a ripple. Stick to the topic that is near to your heart. Anywhere you start, that is the same procedure.

De Leon: Minor questions po para lang pampagana (some trivial questions) [laughing out loud]. First, what is the last book that you read, Father?

Mercado: The Breviary [laughing out loud].

De Leon: What is your favorite food, Father?

Mercado: Ah, I prefer vegetables and fish. I tried to eliminate meat in my diet.

(C) 2016 Emmanuel C. De Leon and Marvin Einstein S. Mejaro http://www.kritike.org/journal/issue 19/de leon\&mejaro december2016.pdf ISSN 1908-7330 
De Leon: What is your favorite place here in UST?

Mercado: Favorite place? Maybe the library.

Mejaro: Nice one, Father! Library [laughing out loud].

De Leon: That's all, Father. Maraming salamat po! (Thank you very much!)

Mercado: Are you doing your M.A. or Ph.D.?

Mejaro: Ph.D. po. This interview will help us a lot in writing our dissertation.

Mercado: Good luck sa inyo at pagbutihin ninyo! (Good luck and excel with what you are doing!)

\author{
End of interview \\ Department of Philosophy, University of Santo Tomas, Philippines
}

\title{
References
}

Alejo, Albert, 'Tao po! Tuloy': Isang Landas ng Pag-unawa sa Loob ng Tao (Quezon City: Office of the Reaearch and Publications - School of Arts and Sciences, Ateneo de Manila University, 1990).

Batoon, Emmanuel, "Tracing Mercado's Anthropological Perspective (First of Two Parts)," in Kritike, 8:1 (2014).

"Tracing Mercado's Anthropological Perspective (Second of Two Parts)," in Kritike, 8:2 (2014).

Gripaldo, Rolando, Filipino Philosophy: A Critical Bibliography, 1974-1997, 2nd edition (Manila: De La Salle University Press, Inc., 2000).

Mercado, Leonardo N., "Why I Started to Write on Filipino Philosophy," in Essays on Filipino Philosophy (Manila: Logos Publications, Inc., 2005).

Pada, Roland Theuas DS., "The Methodological Problems of Filipino Philosophy," in Kritike, 8:1 (2014). 


\section{Appendix 1: A Bibliography of Fr. Leonardo Nieva Mercado, SVD (by Emmanuel C. de Leon)}

\begin{tabular}{|c|}
\hline \\
\hline $\begin{array}{l}\text { Filipino Philosophy. Tacloban City: Divine Word University } \\
\text { ion. }\end{array}$ \\
\hline $\begin{array}{l}\text { Filipino Theology. Tacloban City: Divine Word University } \\
\text { n. }\end{array}$ \\
\hline $\begin{array}{l}\text { igious Psychology. Tacloban City: Divine Word University } \\
\text { lons. }\end{array}$ \\
\hline $\begin{array}{l}\text { no Philosophy. Tacloban City: Divine Word University } \\
\text { is. }\end{array}$ \\
\hline $\begin{array}{l}\text { pino Religious Psychology. Tacloban City: Divine Word } \\
\text { ublications. }\end{array}$ \\
\hline ipino Ethics. Tacloban City: Divine Word University \\
\hline $\begin{array}{l}\text { Psychology for Village Development. Tacloban City: } \\
\text { University Publications. }\end{array}$ \\
\hline $\begin{array}{l}\text { ught on Man and Society. Tacloban City: Divine } \\
\text { s. }\end{array}$ \\
\hline $\begin{array}{l}\text { 1981. Christ in the Philippines. Tacloban City: Divine Word University } \\
\text { Publications. }\end{array}$ \\
\hline $\begin{array}{l}\text { ch Methods in Philippine Context. Tacloban City: Divine } \\
\text { ersity Publications. }\end{array}$ \\
\hline $\begin{array}{l}\text { 2, E Filipino. Tacloban City: Divine } \\
1984 .\end{array}$ \\
\hline and Dialogue: Theory and Practice. \\
\hline $\begin{array}{l}\text { Ielanesia: An Ecumenical Survey. Mount Hagen: } \\
\text { naries. }\end{array}$ \\
\hline $\begin{array}{l}\text { Experience and Non-biblical Revelation. Manila: Logos } \\
\text { ac. }\end{array}$ \\
\hline 1992. Inculturation and Filipino Theology. Manila: Divine Word Publications. \\
\hline $\begin{array}{l}\text { 1993. Co-editor with Maxwell Felicilda. Philippine Muslim-Christian } \\
\text { Dialogue, co-edited by Maxwell Felicilda. Manila: Logos } \\
\text { Publications, Inc. }\end{array}$ \\
\hline $\begin{array}{l}\text { 1994. The Filipino Mind. Washington D.C.: The Council for Research in } \\
\text { Values and Philosophy and Divine Word Publications. }\end{array}$ \\
\hline $\begin{array}{l}\text { 1994. Working with Indigenous People: A Philippine Sourcebook. Manila: Divine } \\
\text { Word Publications. }\end{array}$ \\
\hline
\end{tabular}

(C) 2016 Emmanuel C. De Leon and Marvin Einstein S. Mejaro http://www.kritike.org/journal/issue 19/de leon\&mejaro december2016.pdf ISSN 1908-7330 
1997: Doing Filipino Theology. Manila: Divine Word Publications.

2000. Filipino Thought. Manila: Logos Publications, Inc.

2000. Editor. Inter-religious Stories and Experiences. Manila: Logos Publications, Inc.

2000. Editor. Filipino Popular Devotions: The Interior Dialogue Between Traditional Religions and Christianity. Manila: Logos Publications, Inc.

2001. El Shaddai: A Study. Manila: Logos Publications, Inc.

2001. Old Cultures Renewed Religions: The Search for Cultural Identity in a Changing World. Manila: Logos Publications, Inc.

2001. Remebering Lito and the Past. Manila. Published by the author for private circulation.

2004. Inter-religious Explorations: The Challenge and Rewards of Inter-religious Dialogue. Manila: Logos Publications, Inc.

2005. Essays on Filipino Philosophy. Manila: Logos Publications, Inc.

2006: Political and Legal Philosophies: Western, Eastern, and Filipino. Manila:

Logos Publications, Inc.

2009. Dialogue and Faith: A Philippine View. Manila: Logos Publications, Inc.

2009. Explorations in Filipino Philosophy. Manila: Logos Publications, Inc.

2013: Power as the Holy Spirit and Grace. Manila: Logos Publications, Inc.

\section{Articles}

1964. "Missionary Aggiornamento," in World Mission 15.

1965. "Roots of International Priestly Conflict," in The Homiletics and Pastoral Review 66.

1967. "Calm and Storm" (a short story under the pseudonym Mateo M. Nieva), in Philippine Free Press. January 28.

1968. "Conversion in the Cursillo," in Boletin Eclesiastico de Filipinas 42.

1969. "The Two Views on the Church," in Philippiniana Sacra 4.

1970. "Ilocano Death Practices and Beliefs" (co-author with Selesio V. Flores), in Ilocos Review 2.

1971. "Filipino and Non-Filipino SVD Relationships," in Nova et Vetera.

1972. "A Philosophy of Filipino Time," in Solidarity 7: 5.

1972. "Filipino Thought," in Philippine Studies 20:2.

1972. "How Religious Harmony Changed a Town," in Now Magazine. September 9.

1972. "On Filipino Identity and Intellectual Colonialism," in Now Magazine. September 5.

1972. "Reflections on Buut-Loob-Nakem," in Philippine Studies 20:4.

1974. "Notes on the Filipino Philosophy of Work and Leisure," in Philippine Studies 22:1-2.

1974. "The Filipino and the World of Things," in Verbum SVD 14. 
1976. "Notes on the Filipino Philosophy of History." Unitas 49.

1978. "The Role of the Religious in the Indigenization of Liturgy and Prayer," in Boletin Eclesiastico de Filipinas.

1980. "Notes on Christ and Local Community in the Philippine Context," in Verbum SVD 21.

1980. "Ang Pananaw sa Daigdig ng Cebuano." Ang Weltanschauung ng Pilipino. Compiled by Virgilio G. Enriquez. Manila and Singapore: Surian ng Wikang Pilipino and Institute for Southeast Asian Studies.

1983. "Philosophy of Knowledge in the Philippines." Research Methods in Philippine Context. Edited by Leonardo N. Mercado. Tacloban City: Divine Word University Publications.

1984. "An Intellectual History of Filipino Legal Philosophy," in Solidarity 99.

1985. "A Synthesis of Filipino Thought." Karunungan 2.

1987. "Renewal Movements in the Philippines," in Catalyst 17.

1988. "Melanesian Philosophy," in Catalyst 18.

1988. "The Holy in Filipino Thought," in Diwa 14.

1989. "Holy in the Analects of Confucius," in Sophia 19.

1989. "Power and Spiritual Discipline Among Philippine Folk Healers," in Dialogue and Alliance 3 Winter.

1989. "The Abupera Program: An Alternate Seminary Model for Melanesia?," in Catalyst 19.

1990. "The Filipino as Individual." Readings in Filipino philosophy, comp. DLSU Philosophy Department. Manila: DLSU Press.

1991. "Inculturation and Biblical Apostolate," in Philippiniana Sacra 26:76.

1991. "Soul and Spirit in Filipino Thought," in Philippine Studies 39:3.

1991. "The Filipino Image of God," in Philippiniana Sacra 26:78.

1992. "Kagandahan: Filipino Thought on Beauty, Truth, and Good," in Karunungan 9.

1992: "Filipino Face of Christ," in Philippiniana Sacra 27/79.

1993. "A Paralysis of Dreams," in Philippine Daily Inquirer. September 8.

1993. "Lusot and Filipino Philosophy," in Verbi Praecones: Festschrift fur P. Karl Mueller, SVD zum 75. Edited by Kurt Piskaty and Horst Rzekowski. Nettelal: Steyler Verlag.

1994. "Filipino Microcosms." in Unitas 67.

1995. "Language as Methodology for Filipino Thought," in Unitas 68.

1995. "Philippine Shamanism and Inculturation," Philippiniana Sacra 30/90.

1996. "Descartes and Ecology," in Unitas 69:4.

1996. "Paradigm Shifts and Religious Tolerance," in Philippiniana Sacra.

1996. "The Filipino Translation of Being," in Diwa 21.

1997. "Bayani: The Filipino Concept of Hero," in Karunungan 10-14.

(c) 2016 Emmanuel C. De Leon and Marvin Einstein S. Mejaro http://www.kritike.org/journal/issue 19/de leon\&mejaro december2016.pdf 


\section{INTERVIEW WITH LEONARDO MERCADO}

\begin{tabular}{|c|}
\hline $\begin{array}{l}\text { 1998. "A Notion of Philosophy," in Karunungan } 15 . \\
\text { 1998. "Muslim and Christian Fundamentalism in the Philippines," in } \\
\text { Philippiniana Sacra 33. }\end{array}$ \\
\hline 1998. "The New Paradigm and Filipino Philosophy," in Karunungan 15. \\
\hline 1999. “On Filipino Ethics," in Karunungan. \\
\hline 2000. "El Shaddai and Inculturation," in Philippiniana Sacra. \\
\hline 2000. "From Pagans to Partners," in Verbum SVD 41. \\
\hline 2000. "Signs and Wonders from the Philippine Perspective," in Karunungan. \\
\hline $\begin{array}{l}\text { 2001. "Filipino Philosophy and Corruption in Government," in Ad Veritatem } \\
\text { 2. }\end{array}$ \\
\hline 2001. “Methodologies in Doing Filipino Philosophy," in Karunungan 20. \\
\hline 2001. “On Evaluating Religious Phenomena," in Karunungan 19. \\
\hline $\begin{array}{l}\text { 2001. “Philosophical Ingredients of the Mindanao Peace-zone." Karunungan } \\
18 .\end{array}$ \\
\hline $\begin{array}{l}\text { 2001. "The Erap Impeachment Trial: People Power } 2 \text { and Filipino Legal } \\
\text { Philosophy," in Karunungan } 18 .\end{array}$ \\
\hline $\begin{array}{l}\text { 2002. "Lakaran: A Filipino Way of Proclaiming Christ," in Studia Missionalia } \\
51 .\end{array}$ \\
\hline 2002: “On Evaluating Religious Phenomena," in Karunungan 19. \\
\hline 2003: “The Filipino as Individual: Loob, Body, Self, Bait.” Karunungan 20. \\
\hline 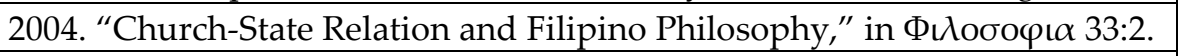 \\
\hline 2004. "Understanding Filipino Causality," in Ad Veritatem 4. \\
\hline 2005. "Philosophy of Gawa (Action)," in Ad Veritatem 5. \\
\hline 2006. "Behind the Media Show," in World Mission xviii:189. \\
\hline $\begin{array}{l}\text { 2007. "Christian and Interfaith Spirituality," in Interpretations for Peace in the } \\
\text { Religions of the Near East. }\end{array}$ \\
\hline 2007. “The Saint of Last Resort,” in World Mission xix:205. \\
\hline 2008. "A Five-Century Devotion," in World Mission xx:209. \\
\hline 2008. "A Poetic Salvation History," in World Mission xx:210. \\
\hline 2008. “Cross-cultural Ministry,” in Philippiniana Sacra. \\
\hline $\begin{array}{l}\text { 2008. "Dancing with the Music: Missionary Spirituality as Experienced with } \\
\text { the Indigenous Peoples and Community," in Institute of Spirituality } \\
\text { in Asia. }\end{array}$ \\
\hline 2008. “The Image of Filipino Faith," in World Mission xx:208. \\
\hline Graduate Studies Works \\
\hline $\begin{array}{l}\text { 1960. Acquired Prudence for Immaturity. Master's thesis, Christ the King } \\
\text { Mission Seminary. }\end{array}$ \\
\hline $\begin{array}{l}\text { 1973. Elements of Filipino Philosophy. Doctoral dissertation, University of } \\
\text { Santo Tomas. }\end{array}$ \\
\hline
\end{tabular}

(C) 2016 Emmanuel C. De Leon and Marvin Einstein S. Mejaro http://www.kritike.org/journal/issue 19/de leon\&mejaro december2016.pdf ISSN 1908-7330 